\title{
Las reglas del juego. Escritura y violencia en la literatura argentina. Guebel, Kartun, Lamborghini
}

\author{
2 NANCY FERNÁNDEZ / Universidad Nacional de Mar del Plata - CONICET \\ nancy.fernandez.cabj@gmail.com
}

\section{Resumen}

En este trabajo procuro analizar algunos textos donde la Forma supone un trato o una experiencia con la lengua y las figuraciones, en torno del cuerpo y la carne como motivos, a partir de los géneros. Consignas y lugares comunes, frases y pantomimas arraigadas en el imaginario nacional y popular. Daniel Guebel, en La Vida por Perón, toma como punto de partida una escena donde el militante de la resistencia, Alfredo (personaje protagónico), toma parte en la versión teatral de Moreira. Mauricio Kartun con El niño argentino, pone a prueba los alcances de las mitologías nacionales y las formaciones históricas de las clases —oligarquía y peonada - desde una obra teatral en verso. En La causa justa, de Osvaldo Lamborghini, la lengua es la matriz de un exotismo que cruza la literalidad imperativa del japonés Tokuro con «la gran llanura del chiste» que ejecutan los empleados argentinos.

Mi propósito es indagar aquellas zonas de la textualidad donde la supuesta especificidad de lo literario propone cruces con otras prácticas simbólicas como el teatro y su instancia de visibilidad.

\section{Abstract}

The aim of this article is to analyze some texts where the form supposes an experience with the language and the figurations about body and meat as leitmotivs, from de the genres. Watchwords, sentences, pantomimes in the popular and national imaginary. Daniel Guebel, in La vida por Perón, takes a scene where the militant of the resistance, participates in a theatrical version of Juan Moreira'story. Mauricio Kartun with El niño argentino, compose a parody of the national mythology and the historical formations of the social class -oligarchy and "peonada», from theatrical work in verse. In La causa justa, by Osvaldo Lamborghini, the language is an exotic matrix that cross the Tokuro's literal imperative with «the great plain of the joke» performed by the argentines employees. I explore the zones of the texts where the supposed specificity of the literature cross symbolical practices as the theater and the instance of visibility.

Key words: writing $\cdot$ theater $\cdot$ violence $\cdot$ visibility $•$ politic 


\section{Introducción. Violencia y tradición}

Cuando se toma por objeto privilegiado la literatura argentina, hablar de tradición y de violencia supone detenerse en ciertos motivos cuya potencialidad funciona como síntoma de aquellas narraciones fundacionales sobre las mitologías de lengua, patria, estado y nación. Y si tradición y violencia asumen los signos móviles de lo político es porque una y otra son los emergentes residuales de las instituciones y no los caracteres orgánicos de los regímenes del poder. Desde mi perspectiva, en la literatura y cultura argentinas (más que literatura y cultura nacional), toman relevancia aquellas claves que inscriben la posibilidad de transformar las conexiones entre autores, poéticas y textos, propiciando una constelación de trazos que puntualizan series, allí donde se abren zonas dinámicas y transdiscursivas. Así, y siguiendo a Ricardo Piglia, puede pensarse que tradición se opone a la noción fija y estática del canon (éste más bien asociado a la operación cultural que realiza Leopoldo Lugones en el contexto del Centenario, mediante Martin Fierro — «La Ida» de I872, "La vuelta» de I879, el mismo año en que Eduardo Gutiérrez publica Moreira — , con el firme propósito de ejercer control e impugnación sobre la oleada inmigratoria). La tradición, entonces, hace posible la apertura plural que proponen aquellos sistemas de citas y filiaciones abiertos a lecturas desacomodadas, perturbadoras, imprevisibles, porque no hacen sino que propiciar la reescritura, en tanto proceso productivo materializado en la semiosis cultural. Tampoco se podría hablar de violencia sin restituir la matriz ideológica, desde Esteban Echeverría y Domingo F. Sarmiento, de Civilización y Barbarie; se trata de seguir los entreveros reales y simbólicos, para discutir un imaginario cuya ficción de origen es, en definitiva, una fábula pecuaria. Y por estas razones, pensar la nación implica mirar sus cuerpos y su materialidad. Así, tanto el lenguaje de la política como las políticas del lenguaje, cruzan préstamos y estrategias que ponen de relieve roles (de representación) y prácticas (de mando o de gobierno); y en las lenguas de cada facción, la de los liberales ilustrados o la de los caudillos federales, se cifran las instancias legitimadoras del nombre propio. En otros términos, si en la literatura gauchesca se negocian las reescrituras, las canónicas y las marginales (marginal en tanto posición adoptada deliberadamente), los retornos y desvíos tramitan las continuidades interrumpidas en las figuras del caudillo, alcanzando su cima en Juan Manuel de Rosas y en Juan Domingo Perón. Tal como se construyen las tradiciones en la Argentina, la fábula nacional es producto de la invención sobre el vacío; y desde Echeverría sabemos que las resonancias metafóricas de tal imagen, tienen su envés en la literalidad de una figuración. Es el espacio inaugural del desierto, esa zona material donde se funda el proyecto de identidad colectiva en los cánones de una lengua culta (los del movimiento romántico). Pero será la extensibilidad que lo caracteriza, aquello que determina su potencial transformación en los repertorios de la falta. El desierto es la nada sobre la que se instala la Conquista, pero será frontera —el linde con el indio—, será suburbio - El Matadero_; también, campo y estancias que gradualmente, asisten a su proceso de modernización (técnicas productivas, alambrados, cauciones
Fecha de recepción: 30/6/20I7

Fecha de aceptación: $28 / 7 / 2017$ 
territoriales — de los malones al ferrocarril—y garantías económicas y propietarias — del saladero a los frigoríficos y la exportación-). El desierto será naturaleza devenido cultura con el afianzamiento de las ideas de progreso y producción. Pero lo que fue intemperie para hordas y malones, va a fluctuar en el campo virgen de vándalos y cuatreros, a falta de genealogías heroicas que sostengan la mitología de una civilización nacional. Si a partir de la Revolución de Mayo y de las luchas por la Independencia se adopta la estrategia de autolegitimación de la figura pública, a lo largo de la historia argentina son cada vez más ostensibles los usos y recursos discursivos que políticos, juristas y militares, despliegan, a través de la prensa, los panfletos y la poesía sobre retratos de sí mismos o sobre los relatos de la nación. Sin embargo, ese «vacío» que, a través de los letrados de la Generación del 37 se hace notar como intemperie injuriosa o como el ideario de una carencia esencial, inscribe desde la ficción del origen un imaginario colectivo en función de la animalidad y su peligro: la amenaza, cuya iconología insiste en las variaciones del rojo sangre. Aquí se cifran las repeticiones y los desplazamientos en torno de la violencia, del rojo vacuno y el de la sangre vernácula, al de las facciones partidarias abiertas desde la enfiteusis rivadaviana y la apuesta simbólica por el valor de la tierra. Se trata de las variantes de un destino anticipado, inscripto en los retornos indelebles de la historia argentina: las facciones partidarias de unitarios y federales, confederados, nacionalistas y autonomistas. De la Mazorca rosista contra los conspiradores de Juan Lavalle, a las organizaciones entre la izquierda y la derecha del peronismo, las repeticiones desplazadas entre violencia y muerte, van fraguando los cuerpos discordantes de la Historia, en los tonos de la ofensiva lúdica, la risa como juego y como fiesta, o el contrapunto que, ya polémico, ya cismático, va dejando su secuela letal. Pero sobre todo, son los signos consuetudinarios del hábito rural (El Matadero - e/I838 y I840- y La Refalosa - $1839-)$ donde las políticas dirimidas entre amigo/enemigo victimizan al disidente. Es en esta tensión, donde la conjura y el desacato propician que el cuerpo, orgánico, ceda a la fragmentariedad de sus componentes; aquí se activan los protocolos de la fetichización que corta o desgarra al cuerpo como carne, cuyo resto en sangre cifra la sustancia de la naturaleza ganadera, sello y propiedad de la oligarquía nacional.

En este sentido, pensar la violencia en relación con la escritura, tanto en las disrupciones fundacionales del siglo XIX como en los asaltos golpistas del siglo $\mathrm{xx}$, supone dar cuenta de un marco histórico según el cual estado y nación (en su proceso gradual de formación) serán los contextos institucionales a partir de los cuales se derivan prácticas subalternas auspiciadas por la Ley/estado, pero instrumentadas como acciones fuera de lo regulado. La serie textual armada sobre El Matadero (Echeverría), La refalosa (Ascasubi), La fiesta del Monstruo (Bustos Domecq) manifiestan las imágenes de lo gregario; todos contra uno, cuando la dinámica cuenta de un modo eficaz la destreza lúdica desplegada como prácticas de muerte, sobre quien no acata los mandatos establecidos. Desde la mirada del liberalismo romántico, el unitario rodeado por los carniceros de El Matadero cumple 
esta función pero también, el Jacinto Cielo de Hilario Ascasubi, frente al acecho del mazorquero. Llegado este punto, cabría reiterar que el relato en primera persona como simulacro de oralidad está mediado por un sistema de enunciación estratégicamente encubierto por los alter egos autorales. Se trata de la representación de una cultura política constituida en los bordes del goce y la fiesta cruel, el desacato y la obediencia forzada, el desacato y la sumisión. En este sentido, las alternancias rituales ligadas al degüello y a la «refalosa» tienen vínculos atávicos muy precisos con el tratamiento animal que como el cepo o la estaquiada son castigos ejemplares en Martín Fierro y en Moreira. Pero la reducción del enemigo en víctima y de víctima en animal tiene su inscripción metonímica más significante en el uso del cuchillo, puñal o facón. En las variables que van de los culpables a los culpabilizados, los castigados ofician como ofrenda expiatoria a la figura de gobernante/ padre/patrón. Y si en el siglo xIx el emblema de este temperamento es Rosas —el aglutinante de la propiedad ganadera-, los rasgos del político-estanciero se actualizan a mediados del siglo xx en los del político afianzado en su popularidad por el desarrollo de la cultura de comunicación de masas. A mediados del siglo $\mathrm{xx}$, radio, cine, televisión se instalan, como medios masivos, en los aliados más funcionales de un sistema de poder y control, donde el imaginario industrial articula, sobre la figura de Perón, lealtades y traiciones en torno de la masa popular. Desde esta perspectiva, en los textos citados, las escenas de violencia extrema culminan en el síntoma común de la fiesta, el goce y la diversión excesiva de un grupo sobre un cuerpo sitiado: eso será el emergente sindicado como el máximo elemento disruptor. Así se cumple el desborde donde es imposible encauzar una relación medios-fines según lo cual la sanción al transgresor garantiza el concepto institucional, la palabra de la Ley como dispositivo jurídico de la nación.

Cuando las representaciones de la violencia en la literatura y la cultura argentinas hacen que causa y efecto coincidan, lo que esa teleología circular registra es que la nación, más allá de ser producto de una narrativa, es también producto del desplazamiento entre juego (exceso y desborde) y sistema (control y poder). En otros términos, se corre el signo entre la regla imperativa de la política (normas de conjunto en función del Estado), y el ejercicio regulador sobre el cuerpo colectivo, cuya práctica disruptiva deja al disidente en situación de víctima acorralada. Y en ese instante o mejor, en este encierro, donde la fuerza de varios se concentra sobre un solo sujeto, literalmente pasivo, el cuerpo es materia viciada en la impresión, la marca, la mácula sacrificial donde la corporalidad sensible se reduce a la pérdida de su concepto. Escribir la violencia, para nosotros, implica fijar el castigo culpabilizando a la víctima animalizada o carneada como res, propiciando un castigo corporal sistemático, en respuesta a programas racionalizados de prácticas políticas. Pero al volverse juego, no solo neutraliza la palabra sino que con ella se contiene el lenguaje porque la razón ya no encuentra asidero. Juego que invoca y convoca, en el sentido de una interpelación consuetudinaria, a la oralidad lúdica de la tradición popular: danza y canto coral, la contragesta bucólica de la figuración rural. 
Si tal como lo habían planteado Theodor Adorno y Max Horkhaimer en Dialéctica del Iluminismo, la violencia es un elemento en ciernes desde el origen de la modernización, la violencia, como matriz fundante y sostenida en la cultura y literatura argentinas, extrema el proceso y los efectos de una política interrumpida en el curso de su formulación. Mientras el siglo xIX ponía de manifiesto el tiempo lento que media entre la formalización (las guerras de Independencia, los diagnósticos de la Generación del 37, desde Echeverría a Sarmiento y Alberdi, entre otros) y la realización de un proyecto, cuyo punto de anclaje es la coalición oligárquica liberal de I880, a partir de 1930, se aceleran los cortes de una disrupción estructural. Año del primer golpe de estado que ejecuta José Félix Uriburu contra Hipólito Yrigoyen, 1930 inscribe para el siglo xx la discontinuidad política cuya visibilidad se agudiza entre los períodos «democráticos», los dictatoriales y los gobiernos peronistas (las comillas subrayan la proscripción del peronismo a partir de la autodenominada Revolución Libertadora en 1955). Asimismo, cabría destacar la tendencia cultural al oxímoron, en tanto un término como «revolución» queda obliterado en el falseamiento de su constitutiva significación.

En cierto modo, desde esta perspectiva y ajustando el lente hacia Latinoamérica, Ángel Rama en La ciudad letrada, distingue aquellos escritores y artistas que, durante el fin del siglo de la modernización, se vinculan con la política más que con el Estado. En esta línea tanto Julio Ramos como Graciela Montaldo señalan la actividad de ciertos autores disidentes en relación con el Estado, a diferencia de aquellos beneficiarios de pactos, alianzas y transacciones con el mismo, donde podríamos ubicar en una primera fase histórica, a Manuel Gálvez, a Ricardo Rojas y a Leopoldo Lugones, en miras a la planificación de prácticas públicas para la configuración de una subjetividad colectiva y civil. Así, son ellos en definitiva quienes sostienen que el discurso sobre la representación, siempre implícito en la teoría de la cultura debe ser comprendido en conexión con los debates sobre educación y con el tipo de sujeto formado por o contra el estado emergente.

En tanto la civilización (sus figuraciones y discursos, sus formas y estrategias de representación) deviene corte, relato y transcurso, sus ficciones acentúan los trazos de la diferencia y la alteridad: gauchos y caudillos en la Generación del 37, la primera corriente inmigratoria hacia fines del siglo XIX, su expansión en la época del Centenario, que derivará en la operación cultural de Lugones, sobre la base de la construcción de un mito nacional. No debería sorprender entonces que Martín Fierro regrese en I879 a pedir trabajo y aconsejar la paz. Ahora y mediante Lugones, Fierro es el rostro de la nación, que reintegrado al mismo sistema que lo había expulsado, vuelve, no solo con la anuencia del aparato gubernamental, sino por pedido expreso de las instituciones que buscan un antídoto contra la multitud inmigratoria. Si seguimos los argumentos de Adorno y Horkhaimer, en el caso argentino, el Centenario cumple esa función homogeneizadora para la construcción de fábulas de identidad que resultan funcionales a la hegemonía estatal y a las ficciones de lo nacional que el contexto impone.

Sabemos, entonces, que la multitud, el grupo plural y la masa con connotaciones 
políticas varían sobre la funcionalidad histórica de sus términos, a tal punto que ya hacia mediados del siglo xx con la emergencia y el emplazamiento del peronismo, las multitudes migrantes van a volver a transformar los espacios urbanos de Buenos Aires, desde el interior hacia la capital y los espacios públicos, donde la Plaza de Mayo, lugar de sacralización política de la palabra del líder, inscribirá el imaginario popular, para tomar el aura simbólica de la mitología colectiva. Así, en las tensiones con un aparato estatal que oscila entre la hegemonía excluyente y modernizadora y el estado populista, cuya preceptiva afianza el liderazgo sobre grupos y masas funcionales al modo paternalista (Rosas/Perón), la violencia será el eje controversial que atraviesa prácticas y discursos dirimidos en la toma de partido a favor del proyecto liberal (cita emblemática, Bustos Domecq contra el Monstruo, la figuración innominada de Perón), o bien en las reescrituras experimentales de la historia y de las mitologías (los hermanos Lamborghini, Copi, Néstor Perlongher, Daniel Guebel).

De lo que se trata en géneros, prácticas, discursos y escrituras que intento analizar es del recorte de un problema político y cultural sobre la base de una persistencia desplazada, de una insistencia móvil, mutante: la violencia, unidad estructural mínima, en tanto motivo (estético, ideológico) que atañe a diferentes modelos de figuración, independientes de una idea de totalidad generalizadora respecto de un imaginario de lo real, respecto de configuraciones de subjetividades y de modelos de representación; pero también, la violencia es tema en tanto eje que articula en sus variaciones históricas, seriales y genealógicas, un corpus cuya extensión desde los inicios hasta el presentea firma su potencia significante, su puntualidad intensiva al momento de pensar el sentido de la experiencia de una cultura, de una comunidad, en su partición y disenso constitutivos (Rancière ). Hans Magnus Enzensberger sostiene en Política y delito, que entre asesinato y política existe una dependencia antigua y estrecha que se encuentra en los cimientos y dispositivos de todo poder. Asimismo, dice, ejerce el poder el que puede dar muerte a sus súbditos (mafia/gobierno) pero algo de esta realidad con sus divisores, sus niveles y fronteras puede trasladarse al plano familiar, la constitución de la familia (como clan) en tanto trama de decisiones y preceptivas que los mayores (padres o tutores) disponen con la distribución de derechos y obligaciones (los menores, los hijos, los hermanos). Es notable cómo entre el ejercicio de la legitimación y la política que ejecutan y planifican las preceptivas y los imperativos se articulan los sujetos en función de una determinada comunidad. Josefina Ludmer argumenta en El cuerpo del delito. Un manual, que las ficciones de identidad cultural con delito parecen fundamentar una cultura del delito del menor al postular una subjetividad segunda culpable, y también un pacto. Y aquí cabe recordar a Sigmund Freud, para quien la conciencia de culpabilidad nace en el acto criminal, en la fiesta totémica (parricidio y antropofagia). Así, la culpabilidad de los hijos (de los menores, de los «imberbes», como resuena en la voz de Perón, pronunciando uno de sus últimos discursos) que se inicia con el incesto y el asesinato es el principio de la moral —y represión cultural— engendrada en el 
sentimiento de culpa, tal como se presenta la escena en El fiord. Sin embargo, la historia nacional invierte la fábula atávica y acredita el sacrificio expiatorio de los hijos: la «tribu» montonera. Condena dirimida en sendas figuraciones ancestrales: el decreto paterno y las intrigas por la disputa de los congéneres. En este sentido, la literatura y cultura argentinas elaboraron, en los ripios de su transcurso, una constelación serial de figuraciones ancestrales, donde se juega la incidencia del doble (como alianza fraternal o ajustes de complicidad) y la configuración filial constituida por el crimen y el castigo, la infracción y el poder que descarga toda la fuerza de su presencia omnímoda. El hijo rehén, el hijo traidor, el hijo inocente, el hijo temerario. Relaciones todas que parecen reelaborar la dialéctica amo/esclavo, o al menos plantear una cadena de favores y tributos, allí donde la deuda se eterniza en la instancia filial, de un pago diferido, aplazado con la garantía en doble faz, de la práctica fiable, extendida en el reaseguro de la palabra o del don paterno. Filiación, fiar: creer, con-fiar, pactar en plazo diferido, un préstamo que le devuelve al padre/acreedor el plus de su inversión. Entonces, si hay crédito es la deuda que asegura a la autoridad, el derecho «natural» de la manipulación y el control.

\section{La letra con sangre entra}

De esta manera, podemos trazar un mapa pletórico en desvíos que va desde los inicios (y el desarrollo) de la gauchesca en el siglo XIX, alcanzando un punto culminante a mediados del siglo xx, para intensificarse en los 70 con una agudización de conflictos armados en torno de la figura de Perón vuelto del exilio. En este punto, Leónidas Lamborghini en El solicitante descolocado (I97I-I889), propone una presentación inaugural en la poesía de neovanguardia, desde la figuración del trabajador y militante peronista, derrotado y a la espera; pero también Osvaldo Lamborghini, en el marco del grupo Literal, escribe El fiord (1969) rasgando en la letra el fondo vacío de lo que no es, sino la máscara discursiva de los lugares comunes, los ideologemas cristalizados en la forma de las consignas partidarias. Si el trabajador de Leónidas Lamborghini es el hijo del pueblo que espera con lealtad la señal del Padre, Osvaldo Lamborghini disemina los jirones del cuerpo que el Padre/Perón/El Loco Rodríguez deja como legado — parodia de herencia- a sus hijos militantes antropófagos. Nacimiento y muerte a través de Carla Greta Terón, la fiesta totémica liquida sus tabúes con el auspicio de Atilio Tancredo Vacán/Augusto Timoteo Vandor (el histórico sindicalista), el hijo mayor y el mayor traidor. Un recorrido desde la gauchesca a la actualidad, de la figura del hijo frente al padre, deviene en pagos y rendición de cuentas, remisiones atávicas y hasta bíblicas donde la distribución jerárquica, cultural pero naturalizada a lo largo de los siglos, o literalmente incorporada en tanto condicionamiento de los cuerpos, instituyen políticas de vida, exclusión o muerte en torno a discursos instituidos sobre familia, ley y propiedad. El caso ejemplar de Don Segundo Sombra (1929), de Ricardo Güiraldes funciona a contrapelo de la barbarie violenta porque es la recuperación, utópica por donde se la lea, de 
una identidad con la dotación pecuniaria que refuerza la ley y la propiedad —el alambrado, la estancia, el acta notarial—, el nombre propio y el padre ausente. A partir de ahora, el campo semántico se extiende en los contextos, coyunturas y episodios, y la familia deviene grupo, multitud, manada animal; la ley muta en letra límite donde la verdad y el mandato se inscriben como letra porosa en sus reacomodamientos, lábil en su uso instrumental por parte del poder; propiedad emplazada como promesa de herencia o legado, reafirmación del objeto manipulado, en nombre del padre: bienes, tierra y cuerpos, a disposición de la autoridad del nombre propio. La figura doble del padre/patrón protege o sustrae, elige entre sus hijos, los súbditos, y dirime premios y castigos entre obediencia y disputa. El padre/patrón recorre y transforma los imaginarios políticos, haciendo visibles los usos deliberados de su ideología de acuerdo al mito o a la desmistificación. Entonces, los pactos y alianzas iniciales se transforman derivando en pugnas entre menores, segundos, lucha carnal entre hermanos. $\mathrm{O}$ bien: como una partición violenta e involuntaria donde solo sobrevive uno (Fierro y Cruz; Moreira y Julián); o como disputa criminal donde la sangre (la del vínculo y la de los cuerpos), termina por dirimir el predominio del sobreviviente. «El delito es, como en Freud, un instrumento crítico porque funciona como frontera cultural que separa la cultura de la no-cultura»; así funciona, la civilización y la barbarie, la constitución de una moral, y la naturaleza que proviene del atavismo primordial y de la pulsión inconsciente que los cuerpos no terminan de reprimir.

El hijo encarna el rol de una subjetividad segunda y culpable, la que toma el "camino equivocado", encontrando su carga real, imaginaria y simbólica, en la significación histórica de la década del 70 del siglo xx: la columna de Montoneros. Allí es cuando Perón, o el Padre/Líder, opta por el ala derecha y echa a sus hijos luego del escarnio público de un insulto transmitido en cadena: «estúpidos que gritan, esos imberbes». Sobre ese punto de inflexión se inscribe La Vida por Perón (2004), de Daniel Guebel. Aquí es donde el autor reconstruye la genealogía de los equívocos que, como un vaudeville nacional, se producen en el sistema de creencias de Montoneros como producto de su propia fantasmagoría y construcción. La novela de una farsa trágica tiene como núcleo el desencuentro entre la imagen que Montoneros tiene (y proyecta) de sí, más los usos y lecturas que Perón auspicia y reparte entre el ala derecha del movimiento y la masa popular. En este sentido, la invectiva pública infligida sobre la juventud peronista desmontará esa imagen pública con la doble historia de militantes y familiares, de actores y asistentes, jaqueando lo real entre la escena manifiesta de la actuación teatral y la otra escena que encubre el objetivo: el cadáver de Perón como botín de guerra, de revancha, o como tótem de fiesta profana. No es casual que La vida por Perón, con el peso histórico que la frase-título tiene en la cultura argentina, esté dedicada por Guebel a su padre (quien le cuenta la anécdota del falso difunto) y a Luis Ziembrowski, significativamente, un actor argentino que le relata algo similar y que, junto al autor, es co-guionista del film (además de interpretar uno de los personajes protagónicos, Rafael, el dirigente montonero en la ficción). Incluso 
en La carne de Evita (20I2), Guebel hace explícita su concepción del peronismo como matriz narrativa. En La vida por Perón, la comedia que concluye como tragedia, no hay parodia de hechos documentados, sino más bien estilización, sin imperativos de homenaje, sobre el verosímil del lenguaje histórico de clases y grupos sociales. Y el extrañamiento que provoca el texto radica precisamente en el reconocimiento del objeto de representación en sincronía con el imprevisto o con su transformación simultánea: de ahí el tono de humor que supone una verdadera distancia irónica. De allí también, que la incursión en las jergas de Montoneros y los prosélitos históricos extreme los efectos de un vacío de sentido potenciando un delirio demencial. De este modo, la escena de inicio, tanto la del ensayo y versión libre de Moreira como la de la mímica grotesca del funeral del padre (muerto «casualmente» el mismo día que el General), enlazan el simulacro histriónico como marco y escenario de una ficción teatral, desplegada en su real visibilidad, al menos en tres niveles: a) el velorio del padre de Alfredo, el joven protagonista que hacia el final descubre el asesinato de su padre para falsificar el cadáver de Perón; b) la puesta en escena de Moreira; c) las exequias reales del líder y el masivo séquito popular. Pero me voy a detener en la reescritura/fragmento de Moreira, como indicio especular del malentendido estructural de la obra.

1973-1974. En ese lapso se define el marco que dota de sentido a una serie de acciones erráticas. No puede pasar desapercibido que el narrador de La vida por Perón apunte a los ojos entrecerrados de Alfredo, el protagonista, fijados sobre las fotografías de Ezeiza. El retorno del exilio y la masacre que le sigue tiene sus rastros previos en los discursos de Perón que Guebel reelabora como monólogos vacilantes entre las figuras de Martin Fierro o del Viejo Vizcacha; esto es, adoptar el rol de padre abnegado o girar como un prestidigitador hacia su filiación más poderosa y funcional. Ezeiza tuvo entre sus oradores al cineasta Leonardo Favio, quien en 1973 estrena su película Moreira. Y la versión «vanguardista» de Moreira, en Guebel, es la entrada de Alfredo como apuntador y de Norma, la compañera militante del joven que lo va a buscar "por una misión secreta» pero que se convierte, momentáneamente, en una espectadora activa. Como siempre, Moreira afirma una coyuntura violenta o disruptiva; si en Favio es Ezeiza, Guebel restituye, en los comienzos del segundo milenio, esa misma escena en un ámbito barrial y la completa con los formularios de un acta de defunción.

Norma mira el ensayo desde su rol de militante, dogmática y clandestina. Así, salta sin mediación de la butaca al escenario para increpar a la actriz que interpreta a la mujer de Moreira: «jy a usted no le da vergüenza pagar por su hombre?». Es notable que entre estos ademanes de imperativos morales, tanto la China en su desprendida generosidad como Moreira, prófugo de la justicia, rompan con los moldes culturales que imponen el gesto de la «hombría de bien», incompatible con el fugitivo delincuente, jugador y mantenido. En este sentido, el Moreira de Guebel borra los contornos de las subjetividades al potenciar su violencia hacia distintos planos de sus signos nacionales: en este caso, y muy precisamente, la de no ajustarse a ningún canon cultural. No es casual, entonces, que La vida por 
Perón recupere la escena teatralizada de un texto cuyo original, en i879, supone una ruptura y un desajuste con el relato predominante como ficción del progreso positivista. No es casual ni por lo que la novela folletín de Eduardo Gutiérrez supuso para la literatura argentina, ni por la incidencia que el teatro tiene en la producción de Guebel. Quizá sea la impronta visual inherente al género lo que pone de manifiesto el vínculo estructural entre espectáculo y malentendido, puesta en escena de acciones conspirativas y el sentido imposible de un sistema de creencias insostenible: ser los hijos dilectos de Perón, los abanderados del Pueblo, los iluminados. En cierta forma, los monólogos de los personajes (el de Perón mediado por el recuerdo de Rafael, por ejemplo), certifican la instancia de autoafirmación; cada palabra será ademán de una expresión ciega, la de una representación mesiánica que desconoce su excentricidad. Y allí donde cada gesto precipita el final de un desatino, la pantomima del peronismo recupera con Moreira la trama nacional de acusaciones y alegatos.

Osvaldo Lamborghini hacía una distinción entre ser y representar pensando figuras diferentes de lo femenino (ver Correspondencia, citado en Strafacce): aquella que es mujer y la que se representa a sí misma como tal en un repertorio de roles. Leyendo a Guebel podría pensarse que Norma está representando su papel de militante. Y esto que el autor resalta de «hacer de», lo hace simultáneamente tanto con los funerales de Perón como con el velorio doméstico del ferroviario, que son puestas en escena del sentido trágico llevado al punto más visible del absurdo nacional. El fracaso de las creaciones (la dramatización libre de Moreira) o de la finalidad trunca del complot que compone la «resistencia» asumen la forma fantasmagórica de eso que se aparta de las proyecciones (las imágenes) concebidas como si se bastaran a sí mismas. Se trata de las interpelaciones fallidas de una comunidad: las mujeres (Norma como militante y espectadora de Moreira) y el pueblo (que desconoce a los hijos autodesignados). Entonces es allí, en la autonomización de relatos y creencias donde el sentido instala su fuerza descentrada para convertir los acontecimientos de la historia en los efectos del desvío, cristalizados en mitologías y monumentos: las formas de la verdad desprendida de las liturgias del dogma. En La vida por Perón, de Daniel Guebel, el General es el padre/Martín Fierro pero también asume la posibilidad del viejo Vizcacha. Matar a un hombre, precisamente al padre del protagonista y simular, otra vez, la actuación, para desplazar el crimen encubriéndolo con la teatralización produce un nuevo desdoblamiento de la puesta en escena del comienzo con Moreira, obra «de vanguardia» que se ensaya al comienzo del texto. Aquí, el simulacro gesticula su propia exterioridad socavando y destruyendo la identidad esencial: «la ley del Padre». Los «hijos» montoneros, vuelven al padre, al «viejo» que los expulsó de la plaza pública y montan la doble escena necrofílica, el contrabando de cadáveres que signará la historia argentina.

En el teatro de Guebel, la máscara no resiste el molde de la catarsis porque cuando se muestran los rasgos reconocibles (de los discursos de época, de los personajes, o sea, el momento costumbrista de la novela) sin que medie explicación 
causal borra aquellas señales que permitirían una identificación con los acontecimientos instalados, la juridicidad de lo real que funciona en la Historia. La vida por Perón desmonta el dispositivo del discurso estatal desplazando la eficacia de las consignas instituidas en el imaginario popular por el proceso que genera una lengua política (rechazo o adhesión partidaria) y una política de la lengua (las estrategias de representación que marcan la relevancia del orden simbólico). El malentendido en Guebel es punto de partida y de llegada a una realidad cuya matriz es el lenguaje, eso que señala el sentido desviado de la instancia inicial como programa o sistema: el efecto es la significación como pieza suelta y pérdida del dogma nacional.

Entonces, leer la genealogía antes que la historia en tanto cronología lineal hacia una progresión evolutiva marca el lugar de Rosas y Perón como emergentes de un cruce entre naturaleza y cultura, voz y ruido, masa e individuo, estado y nación. Entre estos nombres propios se juega lo auténtico, las figuras emblemas de lo argentino, síntoma y lengua de la Patria, cuya fuerza descarta la determinación mecánica de la vuelta cíclica. De este modo, se repone la instancia neutral («lo» indeterminado, cuya potencia figural liquida relaciones de causa efecto). Rosas y Perón restituyen los restos de una continuidad fragmentaria, las señales de aquello que, desplazado, se repite. De aquí en más, la escritura inscribe la lengua ritual del cuerpo en clave sexuada y política en sincronía con la figura del Padre/ Patrón, (el conductor que ampara y prohíbe). En consecuencia surge la figura de los hermanos, los dobles, las «hordas» con su carga significante de un mundo ancestral, atávico. En términos de Rancière, textos con estas figuras y/o personajes restituyen el inconsciente estético que vuelve desde lo indiferenciado y oscuro, cuyo enigma es el jeroglífico de una voluntad sin ley, el retorno de formaciones discursivas donde lo estético flexiona los contrarios: el saber y el no saber, el pensamiento y el no-pensamiento (esto, menos como opuestos que como la contracara eficaz de un desdoblamiento simultaneo). Los hermanos-amigos sellan o rompen una alianza y llegan a tener, en la historia literaria, una función pertinente y relevante (de Martin Fierro a El fiord, pasando por el Santos Vega de Ascasubi (I85I) — los mellizos de La Flor — a «Las diez escenas del paciente, de Leónidas Lamborghini; «La intrusa» de Borges (1970), «La china» de Bizzio y Guebel: «hermanos» que pactan, matan y traicionan).

Niño Argentino (2006), de Mauricio Kartun, es un texto teatral que repone la problemática mediante el juego con el estereotipo y el lugar común del imaginario de la cultura nacional. En esta lectura que procuro organizar se ven los gentilicios como una suerte de leitmotiv, donde los lugares de centro y margen son desplazados por la mirada irónica de las figuras alternantes que manipulan autor, director y «narrador» (esa presencia vocal entre los personajes del Niño y del Muchacho). La parodia que deconstruye las formaciones discursivas de segmentos histórico-sociales, con su sintaxis de alocuciones estereotipadas de grupos y clases, desmonta la genealogía de la tradición nacional en su línea divisoria, otra vez, literal, de borde y frontera, ahora de campo alambrado, sobre su 
emblemática insignia animal: la vaca, punto de partida y de llegada para ver los disfraces de la civilización y la barbarie. En efecto, el Niño es Argentino porque viaja con su familia en huida obligada para evitar la acusación de estupro. Le sobran credenciales prestigiosas que lo legitiman como hijo y patrón de estancia, así como la arrogancia y el tedio cínico bajo los auspicios de la clase fundadora. Y es su familia el núcleo que representa y sintetiza el poder económico de la oligarquía latifundista nacional; ellos entonces, se embarcan con peones, criados y animales que comienzan por ser proveedores alimenticios: leche fresca para los niños viajeros y un buen peón para ordeñar las ubres en tambos adecuados. Mientras los versos son la clave formal para el contrapunto dialógico entre amo y criado, este último «adopta como suyos» gestos y palabras del Amo, Padre y Protector. Habrá que aguardar el momento indicado para que la gratitud debida pulse la metamorfosis del esclavo en amo criminal. Y en esa gradación donde la voz en off toma el rol de narrador escénico que anota, advierte, apunta y señala, aparece el trazo irónico para revelar las construcciones culturales de espacios y sujetos. Así, autor-narrador puede decir del Muchacho:«pequeño gran gaucho de figuritas»; un oxímoron que pone de relieve los atributos redituables del paisano doméstico, pródigo en humildad y sumisión. Pero el enunciado y el plural de «figuritas» signan la instancia seriada de lo que el statu quo desea e instala. La cultura de masas en la forma del comic aparece aquí, de alguna manera, como señal de las condiciones materiales de producción que hablan de una Argentina de principios del siglo xx, una cultura de la modernidad donde los avatares inmigratorios provocan el lenguaje hiperbólico de un abolengo clasista y criollo. Pero además, la cultura de masas reapropiada por el narrador, en tanto contexto de su formación, no solo pone en plural el sustantivo del dibujo, «las figuritas» (procedimiento que destaca la instancia de su visibilidad), sino que va torciendo la presentación de las imágenes hacia el lado de la caricatura. Del mismo modo, la vaca, una especie de fetiche adorado, al comienzo, por el Muchacho, lleva el nombre de Aurora, marca que la indica como portadora de un carácter nacional (como la canción del símbolo patrio de la bandera) y de una historieta infantil («La vaca Aurora»).

Cabe recordar, de paso, que la historieta es creada por Mirco Repetto en 1939 como personaje secundario en la tira "Don Alfonso", publicada por ese entonces en el diario La Vanguardia. Ya en 1940 se independiza iniciando su propia historieta en la revista Cara Sucia. Su fama llega al fin cuando la tira pasa a la revista Mundo Infantil en I950 y en los 70 a la revista Anteojito donde salía con capítulos continuados. En la moral de la tierra cuyos íconos son carnaza y maíz se corren los telones de la putrefacción vislumbrada por el niño rico en tanto condición genealógica de la clase dominante, que no obstante crece sin medir la potencia transmutadora del poder y los privilegios. De este modo, la «patota del Club del Progreso», señera heredad de la Generación del 8o, es, mediante el cuerpo del Niño, testigo pasivo de la violencia incidental tramada como risa bufa y humillante hacia el peón. Tal parece ser el sentido que toma la forma visceral del asesinato que el sirviente perpetra sobre su señorito y su animal; el carácter ritual 
de un simulacro antropofágico donde la adoración se vuelve traición anticipada, efecto refractario del goce ajeno. Menos que una venganza resentida, el crimen supone la inversión material y racional de la dilapidación y el ultraje conformados como actos de clase. El crimen final es, entonces, el acto intempestivo al asumir la condición histórica y social de quienes ejercen la seducción y el dominio, la aniquilación y el resguardo. Vestirse con las ropas del amo, violar al animal para incorporar, en una comida simbólica, los restos carnales de fundadores y patrones en la instancia ficcional de un nuevo origen.

Un texto como La causa justa (1982), de Osvaldo Lamborghini, instala e insiste en puntuar lo argentino como máscara y simulacro del lugar común. Así, el fútbol y Malvinas son la materia que contrasta dos miradas frente a lo real: la de los argentinos y la del japonés. Se trata del litigio entre lenguas y la lengua - como instancia carnal y sexuada - el motivo para saturar el absurdo. Mientras para los primeros el gentilicio es producto de la broma típica, para el segundo es el imperativo atávico lo que signa su acción y decisión. Así, para los argentinos el error es síntoma de la rutina histriónica de los roles, el litigio lúdico de un enfrentamiento deportivo, laboral o sexual. Dicho en otros términos, el japonés toma literalmente lo que los argentinos toman como chiste. Algo de Kafka en «Ante la ley», quizá, algo de Bourvard y Pecuchet de Flaubert, en la situación de un aprendizaje fallido que la "pareja» de amigos encara para ocupar sus vidas. En La Causa Justa, Tokuro, el japonés y Janski, el polaco, asumen una compañía necesaria de lo que llegará a ser para Tokuro la fatalidad de un amor imposible de admitir. Por ello, algo de tragedia absurda signada por el «chiste», donde la levedad no atempera lo fatídico, indica una broma atravesada por una risa inconsciente ante el equívoco y la falla de la lengua que sin embargo conduce, sin mediaciones, a la verdad subterránea, aquella que late por salir a la superficie. Si puede leerse alguna clave kafkiana es la irrisión imposible de llegar a penetrar la máscara de lo que se oculta como simulacro pero que se muestra en su soporte imaginario: el guardián, ahora, en la severidad de Tokuro. De este modo, en Lamborghini se filtran los desajustes entre las figuraciones de los sujetos (los empleados de la Empresa, los jefes) y las reglas del sentido común. Porque aquí, en los chistes que siguen al partido de fútbol, Solteros vs. Casados, lo que sigue al asado y la borrachera es la verdad que se dice y se muestra en el estado que lo exime de toda falta a la moral y la norma. Los compañeros se prodigan abrazos y amor en las duchas del vestuario, bajo los efectos del alcohol. Pero esa es la dirección correcta: el sentido que no está donde se lo busca, allí donde Tokuro apela a la Verdad de la lengua, a la defensa samurái del honor y la Palabra Cumplida. En una Argentina donde el truco del enunciado es el doble sentido cubierto en el deseo de la conjugación verbal subjuntiva:

- Mirá, hermano, yo te quiero tanto, que lo juro por mi madre te chuparía la pija si fuera puto, sí, te lo juro, y vos sabés que yo no soy puto (...) Fue una vergüenza. Todos (29) se refugiaron en las duchas y lograron trabar la puerta. Desde una ventana parlamentaban con 
el señor Tokuro, inútilmente. —Pero ¿en qué lo hemos ofendido, hombre?- le preguntaba Heredia, el que quería tanto a todos que les chuparía la pija (si fuera puto). Tokuro: El que falta a la palabra falta al honor. (20)

Es precisamente la irrupción del plano del deseo lo que produce el desvarío de la escritura y provoca que en su contorsión aparezca lo real. El deseo es el entre de las lenguas licuadas en la apariencia banal de un entendimiento imposible, donde la fruición del «juego» argentino es simétricamente opuesto a la consigna cultural, milenaria de una palabra de orden. Pero el paroxismo de la acción desplegada en una violencia co-incidental se produce entre el acto sexual entre HerediaMancini («promesa» cumplida), el asesinato de Janski por parte de Tokuro (la defensa del polaco a la multitud de sus compańeros), el reconocimiento final del amor de Tokuro hacia Janski (esa suerte de narrador omnisciente lo acompańa en su monólogo interior), y el harakiri final del japonés (no con el arma debida sino con un cuchillo para asado - la comida nacional de los argentinos-). El cuchillo, complemento y metonimia de la llanura, la "Gran Llanura de los Chistes", como la llama Tokuro, en la plena condición de un conocimiento adquirido. Lo que los argentinos cubren y descubren en el chiste, el japonés adentro y afuera de la «llanura», llega al mismo punto, develarse a sí mismo su propio secreto sin que en su memoria persista algún resto de declaración explícita. Tokuro y Janski fueron amigos y nunca cruzaron ese umbral. Sin embargo, al final la pregunta del japonés alcanza la Verdad Incumplida. Y ante su consciencia admite que sí, que amó a Janski aunque no mediara chiste alguno. El japonés también faltó a la Verdad y eso, aunque en el revés de la forma de Heredia y Mancini, también implica traición por encima de la lealtad. Casados, solteros: machos. Un montaje escénico que no es óbice para la risa y el alcohol que muestran simultáneamente el revés de la máscara: «icómo te quiero hermano, te chuparía la pija, si fuera puto!» (20). Es claro que la frase en condicional subjuntivo, que insiste y se repite, es el signo de una representación fallida, porque si hay una escena de goce, es el círculo — «refalosa» - que se arma en torno de la fellatio obligada por parte del japonés: para el samurái, decir es cumplir, maniática palabra de honor. Mientras para ellos —el colectivo, la formación grupal, la «bandada» que al decir del narrador, teme a un solo pájaro- la representación de roles (los solteros, los casados, los empleados, los activos, los pasivos) se juega sobre la naturalización de lo que son convenciones identitarias, representar supone el imaginario cultural común frente a una concepción de realidad variable según los tonos y oropeles de la lengua (la que habla, la que lame), en contextos de uso y de sentido. Para el japonés devenido samurái y voluntario en Malvinas, jefe de personal — de argentinos- y enamorado silencioso de un empleado polaco, la realidad es producto del sentido literal, transformado en la cadena de préstamos verbales acreditados por la traducción. De este modo, el texto acentúa la banalización (del grupo de los argentinos) y la solemnidad del jefe japonés, tensando el malentendido que genera la decisión final del asiático. Así, la visibilidad del gesto final en el harakiri 
culmina como el trazo súbito, casi epifánico, en tanto rémora de un recorrido lingüístico. ¿Qué otra cosa puede ser tomar a Malvinas como el sustituto fallido de una prenda honorífica, el préstamo de una causa nacional por parte de una interpretación solitaria en sitio ajeno? ¿Qué puede significar entonces el sacrificio final de un amor oculto - el de Janski, asesinado en pleno pasaje de amigo a amante, quien «traiciona» a Tokuro para frenar una tragedia precipitada—, en tanto destino cumplido de las lenguas blindadas? Así queda Janski, entre el Gran Vidrio de la ceremonia oriental (violenta y cortés) y la Gran Llanura del chiste argentino. El fin de una lengua menor —el polaco-, como secuela involuntaria, como interposición sintomática de un desvío malentendido.

Llegado el punto - ficticio- de concluir estas líneas es imposible negar la instancia visual de cada uno de los textos abordados, menos como mera sinestesia y más como condición misma de la praxis de escritura; esto es, hacer de la imagen la impronta material de una puesta escena que supone una elección, ética y estética, entre la matriz de escritura que cada género propone. Es claro que Guebel y Kartun trabajan con y desde el teatro. Pero también es cierto que La causa justa de Lamborghini, ofrece todas las aristas de una suerte de muestra actuada desde la convención naturalizada de los personajes, tanto en el chiste como en el fútbol. $Y$ de eso, precisamente, se trata en Lamborghini: de romper los mitos de la representación. De allí, incluso, que refiera explícitamente al teatro como práctica y que así afirme la literalidad como programa. Y ello se produce reafirmándose en el carácter narrativo de los textos o mejor, en el estatuto de la narratividad. Si hay teatro es porque la imagen cobra una fuerza sustantiva en los tres autores; $y$ si la visibilidad es un aspecto constitutivo, es porque tiempo y espacio enhebran aquellos conceptos en torno de la historia y la cultura argentinas. Será entonces, el territorio, como acontecimiento del exotismo (en tanto forma que vincula imagen, espacio y tiempo), un problema y un motivo donde cada autor permite el trazado genealógico y serial donde la violencia política se convierte en el enigma que restituye (siempre desplazado, siempre devenido) el pasado y su sentido.

\section{Bibliografía}

\section{Corpus}

guebel daniel (2004). La vida por Perón. Buenos Aires: Emecé, 2008. Kartun mauricio (2006). El Niño Argentino. Buenos Aires: Losada. osvaldo lamborghini (1982). La causa justa en Novelas y cuentos iI (edición al cuidado de

César Aira). Buenos Aires: Sudamericana, 2003.

\section{Bibliografía de consulta}

adorno, theodor w. y maX horkhaimer (1960). Dialéctica del Iluminismo. Buenos Aires: Sudamericana. 
ARENDT, HANNAH (2006). Sobre la violencia. Madrid: Alianza.

Benjamin, walter (200I). Para una crítica sobre la violencia. Madrid: Taurus.

CASTORIADIs, CORNelius (1993). La institución imaginaria de la sociedad. Buenos Aires: Tusquets. DIDI HUBERMAN, GEORGE (2OI4). «Volver sensible/hacer sensible», en Judith Butler, Jacques

Rancière, Alain Badiou y otros. ¿Qué es un pueblo?. Buenos Aires: Eterna Cadencia, 69-IOI.

Traducción de Cecilia González y Fermín Rodríguez.

enzensberger, hans magnus (1987). Politica y delito. Barcelona: Anagrama.

FREUD, SIGMUND (198I). Obras completas. Madrid: La biblioteca nueva.

GUebel, DANiel (20I2). La carne de Evita. Buenos Aires: Mondadori.

Ludmer, Josefina (1999). El cuerpo del delito. Un manual. Buenos Aires: Perfil libros.

MONTALDO, GRACIELA (1999a). «Intelectuales y artistas en la sociedad civil argentina en el fin de siglo». Working Paper 4, Maryland: Latin American Studies Center. University of Maryland. (1999b). Ficciones culturales y fábulas de identidad en América Latina. Buenos Aires:

Beatriz Viterbo.

RAMA, ÁNGEL (1984). La ciudad letrada. Montevideo: Comisión Uruguaya pro Fundación Ángel Rama.

Ramos, julio (1995). Paradojas de la letra. Caracas: Universidad Andina Simón Bolívar, Excultura.

RANCIÈRE, JACQUES (2005). El inconsciente estético. Buenos Aires: Del estante.

StrafaCCE, RicARdo (2008). Osvaldo Lamborghini: una biografia. Buenos Aires: Mansalva. 